\title{
SYNTHESIS OF HIGHLY ALKYLATED FUNCTIONALIZED CYCLOPENTADIENES
}

Rainer Koschinsky, Thies-Peter Köhli, and Herbert Mayr*

Institut für Chemie der Medizinischen Universität zu Lübeck Ratzeburger Allee 160, D-2400 Lübeck 1, Federal Republic of Germany

Abstract. Tetra- and pentaalkylated cyclopentadienyl ketones and carboxylic acids are prepared by electrophilic allylation of enolizible 1,3-dicarbonyl compounds and successive acid catalyzed cyclisation.

The pentamethylcyclopentadienyl group is an important ligand in organometallic chemistry, and various synthetic approaches to pentamethylcyclopentadiene and its derivatives have been developed. ${ }^{1}$ We report now a novel and straightforward access to highly alkylated acetyl- and alkoxycarbonylcyclopentadienes, which employs the $\left[3^{+}+2\right]$ strategy, previously developed for the synthesis of cyclopentenes by Lewis acid catalyzed reaction of allyl chlorides with alkenes ${ }^{2}$ or alkynes. ${ }^{3}$<smiles>CC=C(C)C(C)Cl</smiles><smiles>CC(=O)C1=C(C)C(C)=C(C)C1C</smiles>

$3 a(60 \%)$<smiles>C/C=C(\CC)C(C)Cl</smiles>

16<smiles>CCOCC</smiles>

16<smiles>[R]C1=C(C)C(C(C)=O)=C([R2])C1C</smiles>

$3 \mathbf{b}(70 \%)$ $\mathrm{R}^{1} \cdot \mathrm{R}^{2}=\mathrm{CH}_{3}, \mathrm{C}_{2} \mathrm{H}_{5}$ or $\mathrm{C}_{2} \mathrm{H}_{5}, \mathrm{CH}_{3}$<smiles>CC(=O)C1=C(C)C2=C(CCCC2)C1C</smiles>

3c $(60 \%)$

When the allylic chlorides 1a-c (25 mol in $50 \mathrm{ml}$ of $\mathrm{CH}_{2} \mathrm{Cl}_{2}$ ) were added dropwise to a solution of acetylacetone $2 \mathrm{a}(33 \mathrm{mmol})$ and $\mathrm{ZnCl}_{2} / \mathrm{Et}_{2} \mathrm{O}^{4}$ (52 mmol) in $\mathrm{CH}_{2} \mathrm{Cl}_{2}$ (350 ml) at $-20^{\circ} \mathrm{C}$ and kept at $-20^{\circ} \mathrm{C}$ for $1 \mathrm{~d}$ and at $4^{\circ} \mathrm{C}$ for $2 \mathrm{~d}$, the cyclopentadienes $3 \mathrm{a}-\mathrm{c}$ were isolated in 60-70\% yield after workup with aqueous ammonia and chromatographic removal ${ }^{5}$ of small 
amounts of the dihydrofurans $9 a-c$. As expected, traces of isomers $(<5 \%)$ with different orientation of the endocyclic double bonds were detectable in the MMR spectra of $3 a, b$.

The reactions are suggested to proceed via the allylated dicarbonyl compounds 6a-c, (Scheme) which are isolated as the only products when the reactions are carrried out at $-78^{\circ} \mathrm{C} .^{6}$ Treatment of $6 \mathrm{a}-\mathrm{C}$ with $\mathrm{ZnCl}_{2} / \mathrm{Et}_{2} \mathrm{O} / \mathrm{HCl}$ in $\mathrm{CH}_{2} \mathrm{Cl}_{2}$ at $-20^{\circ} \mathrm{C}$ yields the cyclopentadienes $3 a-c(60-70 \%)$ accompanied by small amounts of the dihydrofurans 9a-c (3-20\%). These heterocycles are isolated as the major products, when $6 \mathrm{a}-\mathrm{c}$ are treated with dry $\mathrm{HCl}$ in $\mathrm{CH}_{2} \mathrm{Cl}_{2}$ at $0^{\circ} \mathrm{C}$. As shown in the scheme, the formation of the dihydrofurans $9 \mathrm{a}-\mathrm{c}$ is rationalized by protonation of the Cc-double bond of 6 to give the carbenium 1 ion 7 which attacks at the lone pair of the carbonyl group.

\section{Scheme}

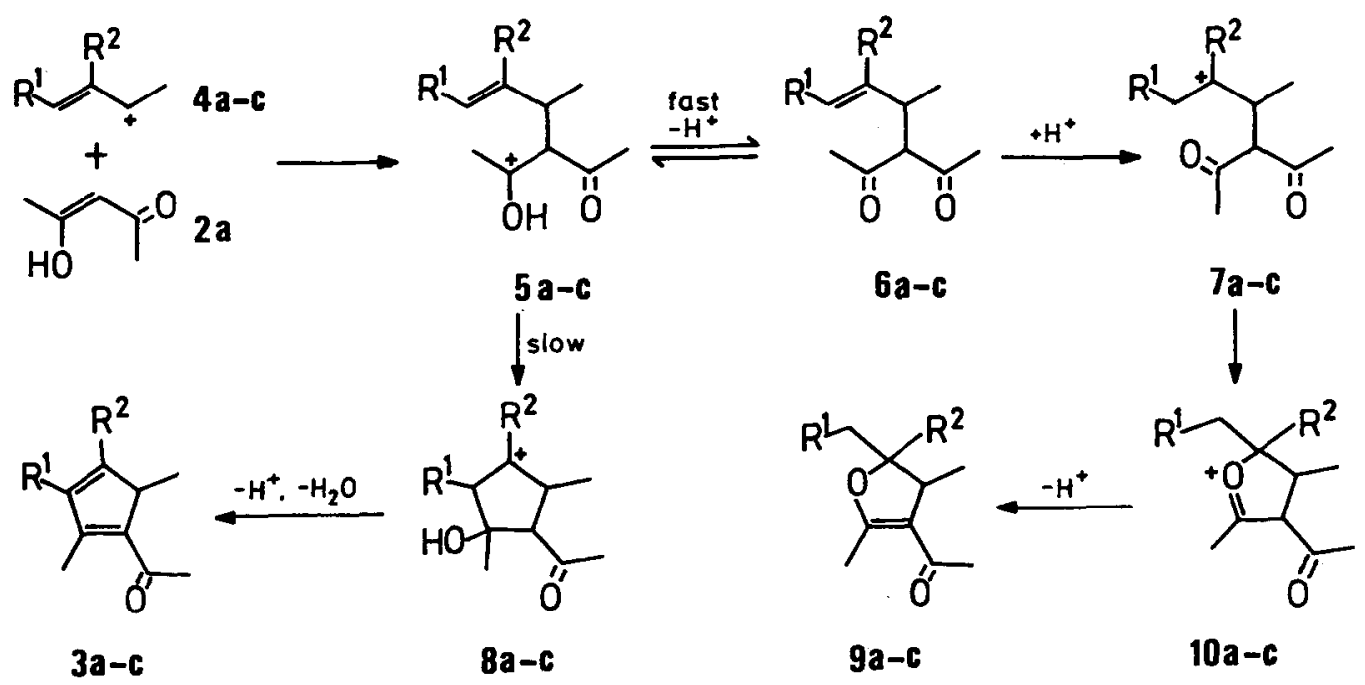

4-10: $a: R^{1}=R^{2}=C_{3} ; b: R^{1} \cdot R^{2}=C_{3}, C_{2} H_{5} ; c: R^{1}-R^{2}=-\left(C H_{2}\right)_{4}^{-}$

When the trimethylallyl chloride $\mathbf{1 a}$ was reacted with the dicarbonyl compounds $\mathbf{2 b}$ - $\mathbf{d}$ under the conditions described above, a complex mixture of compounds was produced, probably because of self-condensation reactions of 1a. The corresponding cyclopentadienes $3 d-f$ are generated, however, when the acyclic products $6 \mathbf{d}-\mathbf{f}$, which are formed from $1 \mathbf{a}$ and $\mathbf{2 b - d}$ in presence of $\mathrm{ZnCl}_{2} / \mathrm{Et}_{2} \mathrm{O} / \mathrm{Et}_{3} \mathrm{~N}$, are treated with one equivalent of $\mathrm{FSO}_{3} \mathrm{H}$ in $\mathrm{CH}_{2} \mathrm{Cl}_{2}$. 
<smiles>COC(=O)CC(C)=O</smiles>

$2 b$<smiles>CC(=O)C(C)C(C)=O</smiles>

2c<smiles>CCOC(=O)C(C)C(C)=O</smiles>

2d<smiles>CC=C(C)C(C)C(C(C)=O)C(C)=O</smiles><smiles>COC(=O)C1=C(C)C(C)=C(C)C1C</smiles>

3d $(48 \%)$<smiles>CC=C(C)C(C)C(C)(C(C)=O)C(C)=O</smiles>

$6 e$

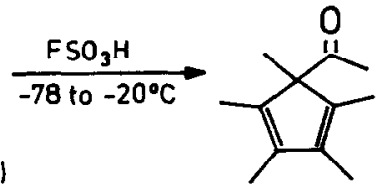

$180 \%)$

3e $(53 \%)$<smiles>CC=C(C)C(C)C(C)(C(C)=O)C(=O)OCC</smiles><smiles>CCOC(=O)C1(C)C(C)=C(C)C(C)=C1C</smiles>

3f $156 \%$

We are presently exploring the scope of this reaction. Until now, we have not yet succeeded to obtain cyclopentadienes from allyl chlorides, which are unsubstituted in the central allylic position" or which carry two alkyl groups at the same allylic terminus.

Table. ${ }^{13} \mathrm{C}$ NMR Chemical Shifts of the Cyclopentadienes 3a- $\mathrm{f}^{3}$<smiles></smiles>

$3 a-d$

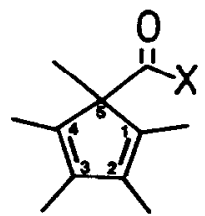

$3 e-f$

\begin{tabular}{|c|c|c|c|c|c|c|c|c|c|c|c|c|c|c|}
\hline & $\mathbf{R}$ & $\mathrm{R}^{\prime}$ & $x$ & $c-1$ & $c-2$ & $c-3$ & $c-4$ & $c-5$ & $1-C$ & $2-c$ & $3-\mathrm{C}$ & $4-c$ & $5-c$ & $X, R, R^{\prime}$ \\
\hline $3 \mathbf{a}$ & $\mathrm{H}$ & $\mathrm{H}$ & $\mathrm{CH}_{3}$ & 142.6 & 154.9 & 135.7 & 150.1 & 49.7 & 194.3 & 14.5 & 10.7 & 12.4 & 14.9 & 30.4 \\
\hline $3 b$, & $\mathrm{CH}$, & $\mathrm{H}$ & $\mathrm{CH}_{3}$ & 143.0 & 154.4 & 141.9 & 149.9 & 49.7 & 194.2 & 14.3 & 18.3 & 12.1 & 15.0 & $30.4,14.1 *$ \\
\hline $3 b_{2}$ & $\mathbf{H}$ & $\mathrm{CH}_{3}$ & $\mathrm{CH}$, & 142.8 & 154.7 & 135.1 & 156.1 & 47.4 & 194.3 & 14.5 & 10.6 & 19.8 & 14.8 & $30.4,14.3^{*}$ \\
\hline $3 c$ & $\mathrm{CH}_{2}-$ & $\mathrm{CH}_{2}$ & $\mathrm{CH}$ & 142.8 & 154.0 & 138.6 & 153.4 & 48.5 & 194.4 & 13.9 & $22.4 *$ & $22.6 *$ & 14.8 & $30.4,22.7^{*}, 23.9^{*}$ \\
\hline 3d & H & $\mathbf{H}$ & $\infty \mathrm{CH}_{3}$ & 131.8 & 156.7 & 135.2 & 149.3 & 49.6 & 165.5 & 13.8 & 10.6 & 12.3 & 14.7 & 50.5 \\
\hline $3 e$ & $\mathbf{H}$ & $\mathrm{H}$ & $\mathrm{CH}_{3}$ & 137.0 & 139.4 & 139.4 & 137.0 & 71.4 & 10.2 & 11.4 & 11.4 & 10.2 & 14.5, & $207.9,22.7$ \\
\hline $3 r$ & H & $\mathrm{H}$ & $\propto_{2} \mathrm{H}_{5}$ & 136.5 & 137.6 & 137.6 & 136.5 & 63.6 & 10.3 & 11.3 & 11.3 & 10.3 & 18.4, & $174.0,60.3,14.3$ \\
\hline
\end{tabular}


Acknowledgement. We thank Ms. Diana Schnoor for experimental assistance and the Deutsche Forschungsgemeinschaft and the Fonds der Chemischen Industrie for financial support.

\section{References and Notes}

1) (a) L. de Vries, J. Org. Chem. 25, 1838 (1960). (b) L. A. Paquette, G. R. Krow, Tetrahedron Lett. 1968, 2139. (c) R. Criegee, H. Grüner, Angew. Chem. 80, 447 (1968); Angew. Chem. Int. Ed. Engl. 7, 467 (1968). (d) M. Kunz, w. Lüttke, Chem. Ber. 103, 315 (1970). (e) R. B. King, A. Efraty, J. Am. Chem. Soc. 94, 3773 (1972). (f) R. B. King W. D. Douglas, A. Efraty, Organic Synth. Coll. Vol. VI, Wiley, New York 1988, p. 39. (g) U. Burger, A. Delay, F. Mazenod, Helv. Chim. Acta 57, 2106 (1974). (h) D. Feitler, G. M. Whitesides, Inorg. Chem. 15, 466 (1976). (i) R. F. Childs, M. Zeya, J. Am. Chem. Soc. 96, 6418 (1974). (j) R. S. Threlkel, J. E. Bercaw, J. Organomet. Chem. 136, 1 (1977). (k) F. X. Kohl, P. Jutzi, J. Organomet. Chem. 243, 119 (1983). (1) U. Burger, R. Etienne, Helv. Chim. Acta 67, 2057 (1984). (m) H. A. Brune, P. Lach, G. Schmidtberg, Chem. Ber. 118, 2671, 2681 (1985). (n) H. Otto, H. Werner, Chem. Ber. 120, 97 (1987). (o) F.X. Kohl, P. Jutzi, Chem. Ber. 120, 1539 (1987).

2) H. Klein, H. Mayr, Angew. Chem. 93, 1069 (1981); Angew. Chem. Int. Ed. Engl. 20, 1027 (1981).

3) (a) J. A. Miller, M. Moore, Tetrahedron Lett. 21, 577 (1980). (b) B. D. Gray, C.M. McMillan, J. A. Miller, M. Moore, Tetrahedron Lett. 28, 235 (1987). (c) B. D. Gray, C. M. MoMillan, J. A. Miller, G. M. Ullah, Tetrahedron Lett. 28, 689 (1987).

4) H. Mayr, W. Striepe, J. Org. Chem. 50, 2995 (1985).

5) In order to prevent decomposition of the products, $\mathrm{NH}_{3}$-saturated mixtures of hexane/ ether have to be used for the chromatographic separations on silica.

6) Examples of other acid catalyzed alkylations of $\beta$-dicarbonyl compounds:

(a) H. O. House "Modern Synthetic Reactions" $2^{\text {nd }}$ ed., Benjamin, Menlo Park, 1972, p. 533. (b) M. T. Reetz, Angew. Chem. 94, 97 (1982); Angew. Chem. Int. Ed. Eng1. 21, 96 (1982).

7) Cf: H. Mayr, H. Klein, G. Kolberg, Chem. Ber. 117, 2555 (1984).

8) The IR and ${ }^{1} \mathrm{H}$ NMR spectra of the previously prepared compounds $3 \mathbf{e}, \mathbf{f}$ agree with literature reports. ${ }^{1}$

(Received in Germany 19 August 1988) 